\title{
Adductor Pollicis Muscle Thickness for nutritional assessment: a systematic review
}

\author{
Espessura do Músculo Adutor do Polegar para avaliação nutricional: uma revisão sistemática \\ Espesura del Músculo Aductor del Pulgar para evaluación nutricional: una revisión sistemática
}

\author{
Priscila Moreira de Lima Pereira', Felipe Silva Neves', Marcus Gomes Bastos', Ana Paula Carlos Cândido' \\ ' Universidade Federal de Juiz de Fora. Juiz de Fora, Minas Gerais, Brazil.
}

How to cite this article:

Pereira PML, Neves FS, Bastos MG, Cândido APC. Adductor Pollicis Muscle Thickness for nutritional assessment: a systematic review. Rev Bras Enferm [Internet]. 2018;71(6):3093-102. DOI: http://dx.doi.org/10.1590/0034-7167-2017-0913

\section{Submission: 01-07-2018 Approval: 05-19-2018}

\section{ABSTRACT}

Objective: The aim of this study is to systematically review the scientific findings about the efficacy of the measure of the Adductor Pollicis Muscle Thickness for nutritional assessment of individuals in various clinical conditions. Method: Systematic review study performed according to the methodology Preferred Reporting Items for Systematic Reviews and Meta-Analyses (PRISMA). Results: 13 original articles published between 2004 and 2016 were included. The measure was associated/correlated to parameters of nutritional status (such as weight, body mass index and Global Subjective Assessment) and muscle mass markers (such as circumference brachial muscle circumference, brachial muscle area, calf circumference, and muscle mass). All these correlations were weak or moderate. Conclusion: The measurement can be used in different populations, being able to estimate nutritional status and muscle mass. However, it is suggested that it be used in a complementary way to the nutritional evaluation, not constituting a single diagnostic/monitoring parameter.

Descriptors: Anthropometry; Nutritional Assessment; Nutritional Status; Body Composition; Weights and Body Measurements.

\section{RESUMO}

Objetivo: Revisar de forma sistemática as constatações científicas acerca da eficácia da medida da Espessura do Músculo Adutor do Polegar para avaliação nutricional de indivíduos em diversas condições clínicas. Método: Estudo de revisão sistemática, realizado conforme a metodologia PreferredReportingltems for SystematicReviewsand Meta-Analyses (PRISMA). Resultados: Foram incluídos 13 artigos originais publicados entre 2004 e 2016. A medida apresentou-se associada/correlacionada aos parâmetros de avaliação do estado nutricional (como peso, índice de massa corporal e Avaliação Subjetiva Global) e aos marcadores da massa muscular (como circunferência braquial, circunferência muscular braquial, área muscular braquial, circunferência da panturrilha e massa muscular). Todas essas correlações foram fracas ou moderadas. Conclusão: A medida pode ser utilizada em diferentes populações, sendo capaz de estimar o estado nutricional e a massa muscular. No entanto, sugere-se que seja empregada de modo complementar à avaliação nutricional, não constituindo um parâmetro único de diagnóstico/monitoramento.

Descritores: Antropometria; Avaliação Nutricional; Estado Nutricional; Composição Corporal; Pesos e Medidas Corporais.

\section{RESUMEN}

Objetivo: Revisar de forma sistemática las constataciones científicas acerca de la eficacia de la medida de la Espesura del Músculo Aductor del Pulgar para evaluación nutricional de los individuos bajo diversas condiciones clínicas. Método: Estudio de revisión sistemática, realizado conforme la metodología Preferred Reporting Items for Systematic Reviews and Meta-Analyses (PRISMA). Resultados: Se incluyeron 13 artículos originales publicados entre 2004 y 2016. La medida se presentó asociada/correlacionada a los parámetros de evaluación del estado nutricional (peso, índice de masa corporal y Evaluación Subjetiva Global) y a los marcadores de masa muscular (como circunferencia braquial, circunferencia muscular braquial, área muscular braquial, circunferencia de la pantorrilla y masa muscular). Todas estas correlaciones fueron débiles o moderadas. Conclusión: La medida puede ser utilizada en diferentes poblaciones, siendo capaz de estimar el estado nutricional y la masa muscular. Sin embargo, se sugiere que se emplee de forma complementaria la evaluación nutricional, no constituyendo un parámetro único de diagnóstico/monitoreo.

Descriptores: Antropometría; Evaluación Nutricional; Estado Nutricional; Composición Corporal; Pesos y Medidas Corporales.

\section{CORRESPONDING AUTHOR Priscila Moreira de Lima Pereira E-mail: priscilamlp_jf@hotmail.com}




\section{INTRODUCTION}

Nutritional assessment is a procedure capable of detecting individuals at nutritional risk, which guides clinical intervention in order to assist the recovery and/or maintenance of health status $^{(1)}$. The analysis of the body composition is of great relevance, since the reduction of muscle mass is an indicator of energy-protein malnutrition, and is generally associated with worse prognoses, such as the fragility syndrome and shorter survival ${ }^{(2-3)}$. However, the methods for the direct evaluation of this compartment are still limited ${ }^{(4)}$.

Lameu et $\mathrm{a}^{(5)}$ suggested the measurement of the Adductor Pollicis Muscle Thickness (APMT), a simple, non-invasive and low-cost procedure. This muscle is flat, fixed between two bone structures and, therefore, the only that can be measured directly, requiring no equations or adjustments to estimate its real value, a fact that highlights it among several anthropometric measurements used for the assessment of muscle mass, such as arm muscle circumference and arm muscle area. Moreover, it undergoes minimal interference of the subcutaneous fat. Nutritional deficits and energy catabolism in malnourished individuals lead to the reduction of APMT, which can also atrophy as a result of physical inactivity ${ }^{(5-7)}$. APMT has been increasingly studied as a nutritional parameter in both sick and healthy subjects. Therefore, it is potentially useful to detect early changes related to malnutrition, besides helping to monitor nutritional recovery ${ }^{(5,7-8)}$.

In 2014, Pereira et $\mathrm{a}^{(9)}$ conducted an integrative review about the evidence of the use of APMT in the evaluation of adults and elderly people. The researchers concluded that it can be used with healthy individuals in various clinical conditions, although there are no cut-off points for all populations. More recently, Lew et al ${ }^{(10)}$ through a systematic review on the validity of APMT to identify the risk of malnutrition in hospitalized adults, concluded that further studies are required to ratify the reliability of this measure and establish its cut-off values before it is instituted as a component of nutritional screening. Despite these studies, there is still no consensus on the association of APMT with other markers of nutritional status and, therefore, on its efficacy as an evaluation tool.

\section{OBJECTIVE}

To systematically review scientific findings about the efficacy of APMT as a tool for nutritional assessment of adult and/or elderly individuals of both sexes in various clinical conditions.

\section{METHOD}

This is a systematic review of the literature performed according to the Preferred Reporting Items for Systematic Reviews and Meta-Analyses (PRISMA) methodology, in order to identify, select and critically analyze relevant studies on the research question ${ }^{(11)}$.

\section{Electronic searches}

The searches were performed by two independent examiners, in July 2017 , strictly complying with the pre-established methodology. The search was delimited from 2004, year in which the pioneer study on the theme was published(5). Previously, there was no mention in the literature of the APMT as an anthropometric parameter, only references on dynamometry, electrical stimulation of the ulnar nerve and acoustic myocytes of the adductor muscle of the thumb $b^{(12-14)}$.

\section{Data source}

The search strategy included the following databases Medline (National Library of Medicine) via PubMed, Lilacs (Latin American and Caribbean Literature in Health Sciences), SciELO (Scientific Electronic Library Online) and Scopus. For Medline and Scopus, the studies were searched in English; for SciELO and Lilacs, the studies were searched in Portuguese and English.

\section{Descriptors}

The following search terms were used: (a) ("thumb adductor muscle" AND "anthropometry") OR ("thumb adductor muscle" AND "nutritional assessment"); ("adductor pollicis muscle" AND "anthropometry") OR ("adductor pollicis muscle" AND "nutritional assessment").

According to the Health Sciences Descriptors (DescritoresemCiências da Saúde - DeCS), as well as the Medical Subject Headings (MeSH), the terms "thumb adductor muscle" and "adductor pollicis muscle" do not consist of controlled vocabulary. However, it was considered essential to use them, since the references of interest mentioned at least one of these terms in their content.

\section{Inclusion criteria}

The inclusion criteria were original studies available in Portuguese and/or English, which analyzed the efficacy of APMT - as measured by the technique recommended by Lameu et $\mathrm{a}^{(5)}$ - as an instrument for the nutritional evaluation of adult and/or elderly individuals, of both sexes, under different clinical conditions, showing estimates for associations/correlations with malnutrition and or markers of nutritional status.

\section{Exclusion Criteria}

Papers of literature review, studies that did not specifically address the subject, and those whose results were limited to the descriptive analysis of APMT without statistical deepening, and therefore did not show associations/correlations with anthropometric variables.

\section{Identification and selection of studies}

After consulting the databases, the studies that were duplicated were detected. The identification and selection were conducted independently by two researchers, who carried out the readings of titles and, later, abstracts. Disagreements in the course of these steps were resolved by consensus.

\section{Eligibility of studies}

After checking the abstracts, the studies that met the inclusion criteria were selected, and the complete versions for the eligibility assessment were read. Disagreements in the course of this stage were resolved primarily by consensus; in the face of continued controversy, a third examiner expressed his opinion. 
Chart 1 - Quality criteria assessed for the confirmation of eligibility of the studies to be included in the review

\begin{tabular}{|c|c|}
\hline Quality criteria & Response \\
\hline 1. Have the research question and objectives been clearly described? & Yes or no \\
\hline 2. Have the ethical aspects been met? & Yes or no \\
\hline $\begin{array}{l}\text { 3. Have the sample calculations and eligibility criteria, as well as the sources and methods of recruitment/selection } \\
\text { of participants been duly presented? }\end{array}$ & Yes or no \\
\hline 4. Were the nutritional assessment procedures reported and consistent with national/international standards? & Yes or no \\
\hline 5. Was the dominance of hands (right-handed or left-handed) considered for APMT measurement? & Yes or no \\
\hline 6. Were the procedures for data analysis performed consistently? & Yes or no \\
\hline 7. Were the confounding factors controlled in the statistical analyzes? & Yes or no \\
\hline 8. Were the results presented clearly and interpreted correctly? & Yes or no \\
\hline 9. Were the limitations of the study, taking into account potential sources of bias or inaccuracy, mentioned? & Yes or no \\
\hline 10. Was the conclusion succinct and appropriate for the research question? & Yes or no \\
\hline
\end{tabular}

Note: Adductor Pollicis Muscle Thickness - APMT

After confirmation of eligibility, a quality questionnaire was prepared by the authors of the study based on the methodological procedures indicated by Armstrong et $\mathrm{al}^{(15)}$, Murad et al $\mathrm{a}^{(16)}$ and Costa et $\mathrm{al}^{(17)}$ (Chart 1). The questionnaire consisted of ten items, with "yes" or "no" answers on clarity in the identification of objectives, ethical aspects, methodological adequacy (sampling, selection/ recruitment of participants and data collection), statistical analysis, presentation/interpretation of results, limitations and contributions of the study. With each statement, the score was assigned "one"; negative responses were scored "zero". For confirmation of eligibility and inclusion in this review, studies should meet at least $70.0 \%$ of these items. The homogeneity between the scores of the two evaluators was verified using the Intraclass Correlation Coefficient (ICC), using SPSS ${ }^{\circledR}$ software (version 20.0; SPSS Inc. ${ }^{\circledR}$, Chicago, IL, USA), with a significance level established at $5.0 \%$.

\section{Constitution of references}

Figure 1 illustrates the flow diagram about the steps of identification, selection, eligibility and inclusion of references.

The examiners evaluated the titles of 106 publications obtained in the databases and then discarded 66 because they were duplicates, and two more by the observation of the title: one was a systematic review of the literature and another was not about the subject. Subsequently, 38 abstracts were checked and 17 were excluded because they did not meet the inclusion/ exclusion criteria. Lastly, a thorough evaluation of 21 complete texts was carried out, resulting in six more eliminations because they did not specifically address the efficacy of APMT in assessing nutritional status and/or because the statistical analyzes were not adequately conducted.

The remaining 15 references were subjected to critical readings, of which two were excluded because they did not reach the minimum value of $70.0 \%$ of quality items. The scores given to the articles included were, on average, $8.3 \pm 0.9$ (first evaluator) and $8.2 \pm 1.9$ (second evaluator). The association between the scores was substantial, with $\mathrm{CCl}=0.98(95 \% \mathrm{Cl}$ : 0.93-0.99, $\mathrm{P}<0.001)$.

\section{Extraction of data}

The results obtained from the studies included a standardized file with their respective information: authorship, year of publication, place of study, design, sample size (n), objectives, characteristics of the sample evaluated (measures of central tendency and dispersion of APMT) and main results.

\section{RESULTS}

From the final sample, 13 studies were published between 2004 and 2016, with only two longitudinal(18-19) and the other with a cross-sectional design ${ }^{(5,7,20-28)}$. Regarding the samples, two studies were carried out with HIV-infected individuals ${ }^{(20-21)}$, two with patients candidates for surgery ${ }^{(7,22)}$, two with patients admitted to the Intensive Care Unit (ICU) ${ }^{(23-24)}$, two with patients in the hospital ward ${ }^{(25,28)}$, two with chronic kidney patients on hemodialysis ${ }^{(18,27)}$ and three with healthy individuals ${ }^{(5,19,26)}$. The characteristics of the studies included in the review are presented in Chart 2. 


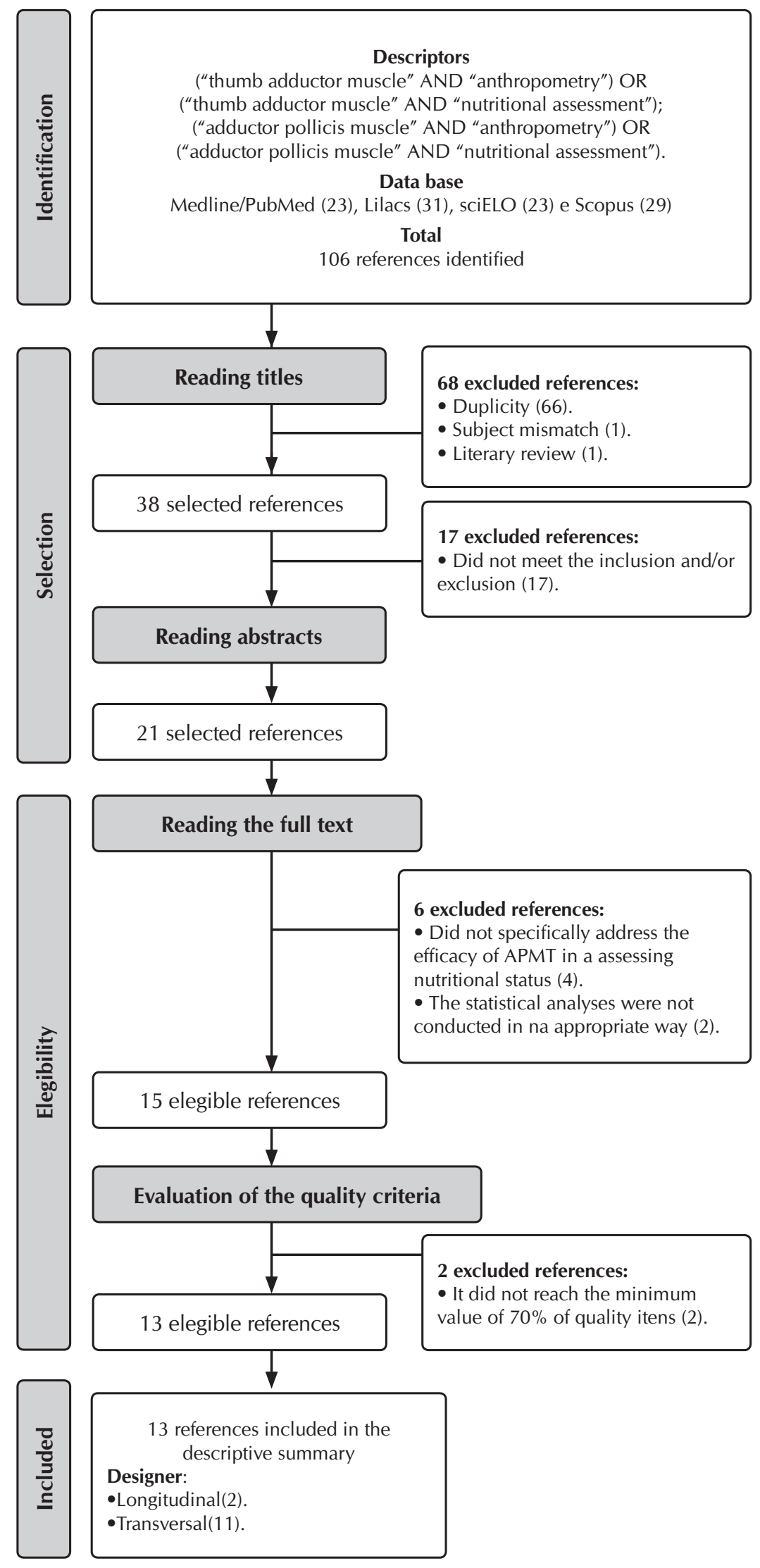

Note: Adductor Pollicis Muscle Thickness - APMT.

Figure 1 - Flowchart on the steps of identification, selection, eligibility and inclusion of references in the review, 2004-2016
All of the studies have properly described the EMAP measurement methodology, as proposed by Lameu et $\mathrm{al}^{(5)}$, and used the simple arithmetic mean from three measurements. Most adopted the Lange $\mathrm{e}^{\circledast 5,7,18-21,25,28)}$ brand analog adipometer, three from Cescorf ${ }^{\mathrm{8}(22,24,27)}$ and two from Vogel $^{\circledR(23,26)}$.

Some studies have shown that APMT presented higher values in males ${ }^{(5,7,18-20,22,26)}$. The measure was also influenced by age, with lower value in older individuals ${ }^{(5,25-27)}$. According to Lameu et $\mathrm{al}^{(5)}$ e Ghorabi et $\mathrm{al}^{(26)}$, the APMT increases progressively up to 65 years and after this age there is a significant reduction. Moreover, in the study by Ghorabi et al $^{(23)}$, the APMT of the dominant hand (APMT-DH) presented values superior to the non-dominant hand (APMT-NDH).

The highest values of APMT were found in the studies of Cortez et $\mathrm{al}^{(20)}$, carried out with outpatients infected with HIV (APMT-DH = $16.2 \pm 4.3 \mathrm{~mm}, \mathrm{APMT}-\mathrm{NDH}=14.8 \pm 4.3$ $\mathrm{mm})$, Ghorabi et $\mathrm{a}^{(23)}$, which included patients of the ICU (APMT-DH = $14.5 \pm 3.6 \mathrm{~mm}$, APMT$\mathrm{NDH}=13.4 \pm 3.6 \mathrm{~mm}$ ), and Bragagnolo et $\mathrm{al}^{(7)}$, with patients who were candidates for large surgery in the gastrointestinal tract (APMT-DH $=12.6 \pm 3.2 \mathrm{~mm}$, APMT-NDH $=12.2 \pm 2.9$ $\mathrm{mm})$. The lowest values were from the studies by Karst et $\mathrm{a}^{(24)}$ carried out with ICU patients at a cardiology hospital (APMT-DH $=8.0 \pm 3.0$ $\mathrm{mm} ; \mathrm{APMT}-\mathrm{NDH}=7.3 \pm 2.7 \mathrm{~mm}$ ), Neves et $\mathrm{al}^{(21)}$, who evaluated patients with HIV from a hospital emergency service (APMT-RH $=9.6$ $\pm 4.7 \mathrm{~mm}$, APMT-LH $=8.9 \pm 3.5 \mathrm{~mm}$ ), and Pereira et $\mathrm{al}^{(27)}$, with patients on hemodialysis $($ APMT $=10.0 \pm 4.5 \mathrm{~mm}$ ).

Chart 3 summarizes the main results of the studies included in this review. In the majority of cases, APMT was correlated with nutritional status [weight, Body Mass Index (BMI), and GSA) and muscle mass markers (Brachial Circumference (BC), Brachial Muscle Circumference (BMC), Brachial Muscle Area (BMA), corrected brachial muscle area (CBMA), Calf Circumference (CC), Muscle Mass (MM) and muscle mass index (MMI)]; nevertheless, all these correlations were weak or moderate $(r<0.70)$. According to Lameu et al(5), APMT was not correlated with body fat assessment parameters, Such as Tricipital Skinfold (TSF) and Arm Fat Area (AFA), but Cortez et $\mathrm{a}^{(20)}$ and Bragagnolo et $\mathrm{al}^{\left({ }^{(7)}\right.}$ detected associations with Waist Circumference (WC) and TS, respectively. Correlations with bone complexion ${ }^{(26)}$, hand grip strength, cell mass, reactance and phase angle ${ }^{(27)}$, creatinine and albumin were also demonstrated ${ }^{(18)}$. 
Chart 2 - Characteristics of the studies included in the review, 2004-2016

\begin{tabular}{|c|c|c|c|c|c|}
\hline $\begin{array}{c}\text { Author } \\
\text { (year) }\end{array}$ & Place & Designing & Objectives & $\mathbf{N}$ & Characteristicsofthesample \\
\hline $\begin{array}{l}\text { Cortez et } \\
\text { al } \underset{(20)}{ }\end{array}$ & $\begin{array}{l}\text { Rio de } \\
\text { Janeiro } \\
(\mathrm{RJ}), \text { Brazil }\end{array}$ & $\begin{array}{l}\text { Cross-section- } \\
\text { alstudy }\end{array}$ & $\begin{array}{l}\text { To estimate APMT and to compare it with im- } \\
\text { munological and anthropometric parameters of } \\
\text { HIV-infected persons. }\end{array}$ & 103 & $\begin{array}{l}\text { HIV-infected outpatients of both } \\
\text { sexes ( } 54.4 \% \text { men), age } 44.1 \pm \\
11.9 \text { years old. }\end{array}$ \\
\hline $\begin{array}{l}\text { Neves et al } \\
(2016)^{(21)}\end{array}$ & $\begin{array}{l}\text { Porto } \\
\text { Alegre } \\
\text { (RS), Brazil }\end{array}$ & $\begin{array}{l}\text { Cross-section- } \\
\text { alstudy }\end{array}$ & $\begin{array}{l}\text { To evaluate the performance of APMT as a } \\
\text { tool for the diagnosis of malnutrition in HIV } \\
\text { infected patients. }\end{array}$ & 48 & $\begin{array}{l}\text { HIV patients from a hospital } \\
\text { emergency, of both sexes }(56.2 \% \\
\text { women), age } 43.0 \pm 11.2 \text { years old. }\end{array}$ \\
\hline $\begin{array}{l}\text { Valente et } \\
\text { al }(2016) \\
(22)\end{array}$ & $\begin{array}{l}\text { Vitória } \\
\text { (ES), Brazil }\end{array}$ & $\begin{array}{l}\text { Cross-section- } \\
\text { alstudy }\end{array}$ & $\begin{array}{l}\text { To evaluate the correlation of APMT with } \\
\text { anthropometric measures, BMI and GSA in the } \\
\text { nutritional diagnosis of surgical patients. }\end{array}$ & 150 & $\begin{array}{l}\text { Patients candidates for surgery, of } \\
\text { both sexes }(56.0 \% \text { men), age } 42.7 \\
\pm 12.0 \text { years old. }\end{array}$ \\
\hline $\begin{array}{l}\text { Ghorabi et } \\
\text { al }(2016) \\
(23)\end{array}$ & $\begin{array}{l}\text { Tehran, } \\
\text { Iran }\end{array}$ & $\begin{array}{l}\text { Cross-section- } \\
\text { alstudy }\end{array}$ & $\begin{array}{l}\text { To evaluate whether APMT is useful in iden- } \\
\text { tifying malnutrition and in predicting clinical } \\
\text { outcomes. }\end{array}$ & 127 & $\begin{array}{l}\text { Patients of a ICU, of both sexes } \\
\text { ( } 54.3 \% \text { women), age of } 51.3 \pm \\
20.4 \text { years old. }\end{array}$ \\
\hline $\begin{array}{l}\text { Biele- } \\
\text { mann et al } \\
(2016)^{(16)}\end{array}$ & $\begin{array}{l}\text { Pelotas } \\
\text { (RS), Brazil }\end{array}$ & Cohortstudy & $\begin{array}{l}\text { To evaluate the relationship between APMT } \\
\text { and muscle mass in a sample of adults. }\end{array}$ & 3485 & $\begin{array}{l}\text { Adults from a } 1982 \text { birth cohort } \\
\text { of both sexes ( } 50.2 \% \text { women). }\end{array}$ \\
\hline $\begin{array}{l}\text { Karst et al. } \\
(2015)^{(24)}\end{array}$ & $\begin{array}{l}\text { Rio } \\
\text { Grande do } \\
\text { Sul, Brazil }\end{array}$ & $\begin{array}{l}\text { Cross-section- } \\
\text { alstudy }\end{array}$ & $\begin{array}{l}\text { To verify the relationship between APMT and } \\
\text { GSA and to correlate it with other anthropo- } \\
\text { metric methods. }\end{array}$ & 83 & $\begin{array}{l}\text { Patients from the ICU of a car- } \\
\text { diology hospital, of both sexes } \\
(62.0 \% \text { men), age } 68.6 \pm 12.5 \\
\text { years old. }\end{array}$ \\
\hline $\begin{array}{l}\text { Gonza- } \\
\text { lez et al } \\
(2014)^{(25)}\end{array}$ & $\begin{array}{l}\text { Pelotas } \\
\text { (RS), Brazil }\end{array}$ & $\begin{array}{l}\text { Cross-section- } \\
\text { alstudy }\end{array}$ & $\begin{array}{l}\text { To test the validity of APMT as a nutritional } \\
\text { parameter in hospitalized patients, using GSA } \\
\text { as gold standard. }\end{array}$ & 361 & $\begin{array}{l}\text { Patients hospitalized in a surgical } \\
\text { ward of both sexes }(60.2 \% \text { wom- } \\
\text { en), age } 49.6 \pm 17.8 \text { years old. }\end{array}$ \\
\hline $\begin{array}{l}\text { Ghorabi et } \\
\text { al }(2014) \\
(26)\end{array}$ & $\begin{array}{l}\text { Tehran, } \\
\text { Iran }\end{array}$ & $\begin{array}{l}\text { Cross-section- } \\
\text { alstudy }\end{array}$ & $\begin{array}{l}\text { To determine APMT in different age groups } \\
\text { and to analyze its correlation with other an- } \\
\text { thropometric parameters in healthy adults. }\end{array}$ & 432 & $\begin{array}{l}\text { Healthy adults of both sexes } \\
(65.7 \% \text { women), age } 37.4 \pm 13.4 \\
\text { years old. }\end{array}$ \\
\hline $\begin{array}{l}\text { Pereira et } \\
\text { al }(2013) \\
(27)\end{array}$ & $\begin{array}{l}\text { São Paulo } \\
\text { (SP), Brazil }\end{array}$ & $\begin{array}{l}\text { Cross-section- } \\
\text { alstudy }\end{array}$ & $\begin{array}{l}\text { To test APMT as a nutritional marker in pa- } \\
\text { tients undergoing hemodialysis. }\end{array}$ & 73 & $\begin{array}{l}\text { Patients on hemodialysis, of both } \\
\text { sexes ( } 57.5 \% \text { men), age } 52.3 \pm \\
17.0 \text { years old. }\end{array}$ \\
\hline $\begin{array}{l}\text { Cobero et } \\
\text { al } \underset{(28)}{(2012)}\end{array}$ & $\begin{array}{l}\text { São Paulo } \\
\text { (SP), Brazil }\end{array}$ & $\begin{array}{l}\text { Cross-section- } \\
\text { alstudy }\end{array}$ & $\begin{array}{l}\text { To verify the association of APMT with anthro- } \\
\text { pometric parameters and GSA in hospitalized } \\
\text { patients. }\end{array}$ & 112 & $\begin{array}{l}\text { Patients hospitalized in wards of } \\
\text { both sexes ( } 59.8 \% \text { men), age } 53.0 \\
\pm 17.0 \text { years old. }\end{array}$ \\
\hline $\begin{array}{l}\text { Oliveira et } \\
\text { al } \underset{(18)}{(2012)}\end{array}$ & $\begin{array}{l}\text { Fortaleza } \\
\text { (CE), Brazil }\end{array}$ & Cohortstudy & $\begin{array}{l}\text { To analyze, in a 12-month period of follow- } \\
\text { up, the correlation of APMT with impedance } \\
\text { markers, anthropometry and laboratory param- } \\
\text { eters, as well as its association with morbidit / } \\
\text { mortality in hemodialysis patients. }\end{array}$ & 143 & $\begin{array}{l}\text { Patients on hemodialysis, of both } \\
\text { sexes }(58.0 \% \text { men), age } 52.2 \pm \\
16.6 \text { years old. }\end{array}$ \\
\hline $\begin{array}{l}\text { Bragag- } \\
\text { nolo et al } \\
(2009)^{(7)}\end{array}$ & $\begin{array}{l}\text { Cuiabá } \\
\text { (MT), } \\
\text { Brazil }\end{array}$ & $\begin{array}{l}\text { Cross-section- } \\
\text { alstudy }\end{array}$ & $\begin{array}{l}\text { To correlate APMT with anthropometric, bio- } \\
\text { chemical and clinical parameters in surgical } \\
\text { patients. }\end{array}$ & 87 & $\begin{array}{l}\text { Patients candidates for large surgery } \\
\text { in the gastrointestinal tract hospital- } \\
\text { ized in the ward, of both sexes } \\
\text { (51.7\% women), aged } 53.8 \pm 15.9 \\
\text { years old. }\end{array}$ \\
\hline $\begin{array}{l}\text { Lameu et } \\
\text { al }(2004)^{(5)}\end{array}$ & $\begin{array}{l}\text { Rio de } \\
\text { Janeiro } \\
(\mathrm{RJ}), \text { Brazil }\end{array}$ & $\begin{array}{l}\text { Cross-section- } \\
\text { alstudy }\end{array}$ & $\begin{array}{l}\text { Provide the first estimates of APMT in healthy } \\
\text { individuals. }\end{array}$ & 421 & $\begin{array}{l}\text { Healthy adults of both sexes } \\
\text { ( } 50.4 \% \text { women), age } 44.9 \pm 19.4 \\
\text { years old. }\end{array}$ \\
\hline
\end{tabular}

Notes: Global Subjective Assessment - GSA; Adductor Pollicis Muscle Thickness - APMT; Human Immunodeficiency Virus - HIV; Body Mass Index - BMI; Sample Size - N; Intensive Care Unit - ICU.

Chart 3 - Main results of the studies included in the review, 2004-2016

\begin{tabular}{|c|c|c|c|c|}
\hline \multirow{2}{*}{$\begin{array}{l}\text { Author } \\
\text { (year) }\end{array}$} & \multicolumn{3}{|c|}{ APMT values (mean \pm standard deviation) } & \multirow{2}{*}{ Mainresults } \\
\hline & Male & Female & Total & \\
\hline $\begin{array}{l}\text { Cortez et al } \\
(2016)^{(20)}\end{array}$ & $\begin{array}{l}\text { APMT-DH }= \\
17.9 \pm 3.9 \\
\text { mm. } \\
\text { APMT-NDH } \\
=16.7 \pm 3.8 \\
\mathrm{~mm} .\end{array}$ & $\begin{array}{l}\text { APMT-DH }^{\mathrm{a}}= \\
14.1 \pm 3.8 \\
\mathrm{~mm} . \\
\text { APMT-NDH }^{\mathrm{a}} \\
=12.5 \pm 3.8 \\
\mathrm{~mm} .\end{array}$ & $\begin{array}{l}\text { APMT-DH }= \\
16.2 \pm 4.3 \\
\mathrm{~mm} . \\
\text { APMT-NDH } \\
=14.8 \pm \\
4.3 \mathrm{~mm} .\end{array}$ & 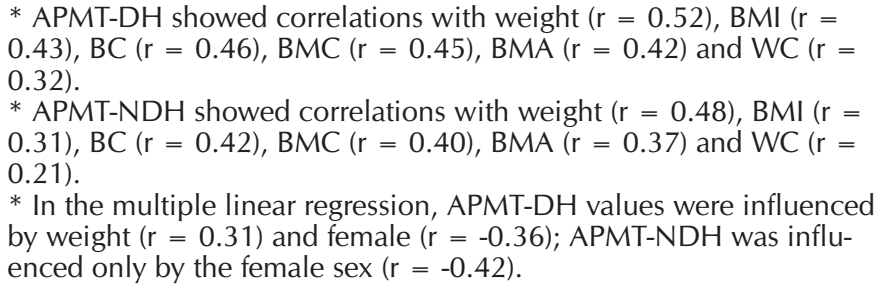 \\
\hline
\end{tabular}


Chart 3 (concluded)

\begin{tabular}{|c|c|c|c|c|}
\hline \multirow{2}{*}{$\begin{array}{l}\text { Author } \\
\text { (year) }\end{array}$} & \multicolumn{3}{|c|}{ APMT values (mean \pm standard deviation) } & \multirow{2}{*}{ Mainresults } \\
\hline & Male & Female & Total & \\
\hline $\begin{array}{l}\text { Neves et al } \\
(2016)^{(21)}\end{array}$ & $\begin{array}{l}\text { APMT-RH }= \\
10.3 \pm 4.5 \\
\text { mm. } \\
\text { APMT-LH }= \\
9.9 \pm 4.2 \\
\text { mm. }\end{array}$ & $\begin{array}{l}\text { APMT-RH } \\
=8.7 \pm 4.7 \\
\text { mm. } \\
\text { APMT-LH }= \\
8.4 \pm 2.4 \\
\mathrm{~mm} .\end{array}$ & $\begin{array}{l}\text { APMT-RH } \\
=9.6 \pm 4.7 \\
\text { mm. } \\
\text { APMT-LH }= \\
8.9 \pm 3.5 \\
\mathrm{~mm} .\end{array}$ & $\begin{array}{l}\text { * APMT-RH showed correlation with current weight }(r=0.32) \text {. } \\
\text { * APMT-LH showed correlations with current weight }(r=0.37), \text { BMI } \\
(r=0.32), B C(r=0.45), B M C(r=0.41) \text { and BMA }(r=0.41) . \\
\text { *APMT values of well-nourished patients }(\mathrm{GSA}-\mathrm{A}=10.5 \pm 3.6 \mathrm{~mm}) \\
\text { were higher than those at risk of malnutrition or malnourishment } \\
\text { (GSA-B + GSA-C }=8.2 \pm 3.2 \mathrm{~mm}) \text {. } \\
\text { *APMT-RH did not differ between GSA-A }(11.7 \pm 6.2 \mathrm{~mm}), \text { GSA-B } \\
(8.6 \pm 3.3 \mathrm{~mm}) \text { and GSA-C }(7.9 \pm 2.1 \mathrm{~mm}) .\end{array}$ \\
\hline $\begin{array}{l}\text { Valente et } \\
\text { al }(2016)^{(22)}\end{array}$ & $\begin{array}{l}27.4 \% \\
\text { presented the } \\
\text { APMT-DH } \\
<13.1 \mathrm{~mm} \\
\text { (cut-off point } \\
\text { for malnutri- } \\
\text { tion) }\end{array}$ & $\begin{array}{l}56.0 \% \\
\text { presented the } \\
\text { APMT-DH } \\
<13.1 \mathrm{~mm} \\
\text { (cut-off point } \\
\text { for malnutri- } \\
\text { tion). }\end{array}$ & $\begin{array}{l}40 \% \text { pre- } \\
\text { sented the } \\
\text { APMT-DH } \\
<13.1 \mathrm{~mm} \\
\text { (cut-off point } \\
\text { for malnutri- } \\
\text { tion). }\end{array}$ & $\begin{array}{l}\text { * The nutritional status defined by APMT was associated with BMI, } \\
\text { GSA and nutritional risk. } \\
\text { * The APMT showed correlations with BMI }(r=0.29), B M C(r= \\
0.33), \text { CBMA ( } r=0.37) \text { and CC }(r=0.32) \text {. } \\
\text { * The variables gender, BMI, BMC and CBMA remained in the final } \\
\text { multiple linear regression model, which explained } 24.0 \% \text { of the } \\
\left.\text { APMT value ( } \mathrm{R}^{2}=0.238\right) \text {. } \\
\text { * BMC was the variable that most influenced APMT, even after adjust- } \\
\text { ing for sex, BMI and CBMA, with a reduction of } 0.392 \mathrm{~mm} \text {. }\end{array}$ \\
\hline $\begin{array}{l}\text { Ghorabi et } \\
\text { al }(2016)^{(23)}\end{array}$ & NR & NR & $\begin{array}{l}\text { APMT-DH }= \\
14.5 \pm 3.6 \\
\text { mm. } \\
\text { APMT-NDH } \\
=13.4 \pm \\
3.6 \mathrm{~mm} .\end{array}$ & $\begin{array}{l}\text { APMT-DH and APMT-NDH showed correlations with BC }(r=0.62 \\
\text { and } r=0.59 \text {, respectively), BMC ( } r=0.68 \text { and } r=0.66 \text {, respective- } \\
\text { ly) and BMA ( } r=0.44 \text { in both). }\end{array}$ \\
\hline $\begin{array}{l}\text { Bielemann } \\
\text { et al (2016) } \\
\text { (16) }\end{array}$ & $\begin{array}{l}\text { APMT-NDH } \\
=24.2 \pm 4.2 \\
\mathrm{~mm}\end{array}$ & $\begin{array}{l}\text { APMT-NDH } \\
=19.4 \pm 3.9 \\
\text { mm. }\end{array}$ & NR & $\begin{array}{l}\text { * APMT showed correlations, in men and women, with MM obtained } \\
\text { by DEXA ( } r=0.44 \text { and } r=0.51 \text {, respectively) and } \mathrm{MMI}(r=0.51 \\
\text { and } r=0.57 \text {, respectively). } \\
\text { * The regression coefficients of APMT in the prediction of MM were } \\
\text { similar for men ( } \beta: 0.7,95 \% \mathrm{Cl}: 0.64-0.78) \text { and women }(\beta: 0.71,95 \% \\
\mathrm{Cl}: 0.65-0.76) \text {. } \\
\text { * The APMT, in men and women, respectively, explained } 19.0 \% \text { and } \\
26.0 \% \text { in the MM variation, and } 26.0 \% \text { and } 33.0 \% \text { in the } \mathrm{MMI} \text { varia- } \\
\text { tion. }\end{array}$ \\
\hline $\begin{array}{l}\text { Karst et al } \\
(2015)^{(24)}\end{array}$ & NR & NR & $\begin{array}{l}\text { APMT-RH } \\
=8,0 \pm 3,0 \\
\mathrm{~mm} \\
\text { APMT-LH }= \\
7,3 \pm 2,7 \\
\mathrm{~mm}\end{array}$ & $\begin{array}{l}\text { * APMT-RH and APMT-LH showed correlations with BMI }(r=0.45 \\
\text { and } r=0.44 \text {, respectively) and CC }(r=0.58 \text { and } r=0.57 \text {, respec- } \\
\text { tively). } \\
\text { * The area under the ROC curve of the APMT-RH with GSA was } 0.82 \\
(95 \% \text { Cl: } 0.73-0.91) .\end{array}$ \\
\hline $\begin{array}{l}\text { Gonzalez } \\
\text { et al (2014) } \\
(25)\end{array}$ & $\begin{array}{l}\text { APMT-DH }{ }^{\ddagger}: \\
\text { GSA-A 23.0 } \\
\text { mm }(21.0- \\
25.0 \mathrm{~mm}) ; \\
\text { GSA-B }=18.0 \\
\mathrm{~mm}(16.0- \\
20.0 \mathrm{~mm}) ; \\
\text { GSA-C }=17.0 \\
\mathrm{~mm}(15.0- \\
18.0 \mathrm{~mm}) . \\
\text { APMT-NDH } \\
\text { GSA-A }=22.0 \\
\mathrm{~mm}(20.0- \\
25.0 \mathrm{~mm}) ; \\
\text { GSA-B }=18.0 \\
\mathrm{~mm}(16.0- \\
20.0 \mathrm{~mm}) ; \\
\text { GSA-C = } 16.0 \\
\mathrm{~mm}(12.0- \\
18.0 \mathrm{~mm}) .\end{array}$ & $\begin{array}{l}\text { APMT-DH }^{\ddagger} \\
: \text { GSA-A } \\
26.0 \mathrm{~mm} \\
(25.0-28.0 \\
\mathrm{mm}) ; \mathrm{GSA}-\mathrm{B} \\
=19.5 \mathrm{~mm} \\
(16.5-22.0 \\
\mathrm{mm}) ; \mathrm{GSA}-\mathrm{C} \\
=18.0 \mathrm{~mm} \\
(15.0-20.0 \\
\mathrm{mm}) \\
\text { APMT-NDH } \\
: \text { GSA-A }= \\
25.0 \mathrm{~mm} \\
(24.0-28.0 \\
\mathrm{mm}) ; \mathrm{GSA}-\mathrm{B} \\
=18.0 \mathrm{~mm} \\
(15.5-20.0 \\
\mathrm{mm}) ; \mathrm{GSA}-\mathrm{C} \\
=16.0 \mathrm{~mm} \\
(15.0-20.0 \\
\mathrm{mm}) .\end{array}$ & NR & $\begin{array}{l}\text { * APMT-DH and APMT-NDH showed correlations with age }(r=-0.28 \\
\text { in both), weight }(r=0.52 \text { and } r=0.56 \text {, respectively), height }(r= \\
0.19 \text { and } r=0.18 \text {, respectively }), B M I(r=0.44 \text { and } r=0.50 \text {, respec- } \\
\text { tively) and GSA ( } r=-0.61 \text { and } r=-0.60 \text {, respectively). }\end{array}$ \\
\hline
\end{tabular}


Chart 3 (concluded)

\begin{tabular}{|c|c|c|c|c|}
\hline \multirow{2}{*}{$\begin{array}{c}\text { Author } \\
\text { (year) }\end{array}$} & \multicolumn{3}{|c|}{ APMT values (mean \pm standard deviation) } & \multirow{2}{*}{ Mainresults } \\
\hline & Male & Female & Total & \\
\hline $\begin{array}{l}\text { Ghorabi et } \\
\text { al }(2014)^{(26)}\end{array}$ & $\begin{array}{l}\text { APMT-DHb } \\
=14.6 \pm 3.2 \\
\text { mm. } \\
\text { APMT-NDHb } \\
=13.7 \pm 3.2 \\
\mathrm{~mm}\end{array}$ & $\begin{array}{l}\text { APMT-DH }{ }^{\mathrm{a}, \mathrm{b}} \\
=11.2 \pm 2.4 \\
\mathrm{~mm} \\
\text { APMT-NDH } \\
=10.2 \pm 2.4 \\
\mathrm{~mm}\end{array}$ & NR & $\begin{array}{l}\text { * APMT-DH and APMT-NDH showed correlations with weight }(r= \\
0.60 \text { in both), BMI ( } r=0.46 \text { er }=0.45 \text {, respectively), BC ( } r=0.51 \\
\text { and } r=0.52, \text { respectively), BMC }(r=0.46 \text { in both), BMA }(r=0.47 \\
\text { in both) and bone complexion ( } r=0.57 \text { and } r=0.56 \text { respectively). } \\
* \text { The APMT was progressively increased according to bone complex- } \\
\text { ion and presented association with age: the value of APMT increased } \\
\text { progressively up to } 65 \text { years, followed by a significant reduction above } \\
\text { that age. }\end{array}$ \\
\hline $\begin{array}{l}\text { Pereira et } \\
\text { al }(2013)^{(27)}\end{array}$ & $\begin{array}{l}\mathrm{APMT}^{+}=10.8 \\
\pm 4.9 \mathrm{~mm}\end{array}$ & $\begin{array}{l}\mathrm{APMT}^{+}=9.0 \\
\pm 3.7 \mathrm{~mm}\end{array}$ & $\begin{array}{l}\mathrm{APMT}^{+}= \\
10.0 \pm 4.5 \\
\mathrm{~mm}\end{array}$ & $\begin{array}{l}\text { * The APMT showed correlations with age }(r=-0.32) \text {, hand grip } \\
\text { strength }(r=0.40) \text {, serum albumin }(r=0.27) \text {, cell mass }(r=0.40) \text {, } \\
\text { reactance }(r=0.27) \text { and phase angle }(r=0.38) \text {. } \\
* \text { There were no correlations with GSA, weight, BMI, BC, BMC, } \\
\text { BMA, MM and serum creatinine. } \\
* \text { In the linear regression analysis adjusted for sex, age and time on } \\
\text { hemodialysis, APMT was a predictor of manual grip strength }(r= \\
0.59) \text {. }\end{array}$ \\
\hline $\begin{array}{l}\text { Cobero et } \\
\text { al }(2012)^{(28)}\end{array}$ & NR & NR & $\begin{array}{l}\text { APMT-DH }= \\
12,4 \pm 5,1 \\
\text { mm. }\end{array}$ & $\begin{array}{l}\text { * The APMT showed correlations with current weight }(r=0.24) \text {, BMI } \\
(r=0.20) \text {, TSF }(r=0.24), \text { CB }(r=0.22) \text { and CC }(r=0.26)\end{array}$ \\
\hline $\begin{array}{l}\text { Oliveira et } \\
\text { al }(2012)^{(18)}\end{array}$ & $\begin{array}{l}\mathrm{APMT}^{+}= \\
12.3 \pm 1.5 \\
\mathrm{~mm}\end{array}$ & $\begin{array}{l}\text { APMT }^{\mathrm{ta}}= \\
11.2 \pm 1.5 \\
\mathrm{~mm}\end{array}$ & $\begin{array}{l}\mathrm{APMT}^{+}= \\
11.9 \pm 1.6 \\
\mathrm{~mm}\end{array}$ & $\begin{array}{l}\text { * The APMT showed correlations with BMI }(r=0.37), B C(r=0.44) \text {, } \\
\text { BMC }(r=0.49), \text { BMA }(r=0.45) \text {, percentage of cell mass }(r=29) \text {, } \\
\text { phase angle }(r=0.40) \text {, resistance }(r=-0.403) \text {, creatinine }(r=0.23) \\
\text { and albumin }(r=0.21) \text {. }\end{array}$ \\
\hline $\begin{array}{l}\text { Bragagnolo } \\
\text { et al (2009) } \\
\text { (7) }\end{array}$ & NR & NR & $\begin{array}{l}\text { APMT-DH }= \\
12.6 \pm 3.2 \\
\text { mm. } \\
\text { APMT-NDH } \\
=12.2 \pm \\
2.9 \mathrm{~mm}\end{array}$ & $\begin{array}{l}\text { * APMT showed correlation with BMI, CB, TSF, and BMC ( } r \text { values } \\
\text { were not reported). } \\
\text { * The APMT of the patients classified with GSA-A was higher than } \\
\text { those with GSA-B and GSA-C. } \\
* \text { In the APMT ROC curves for the identification of protein-energy } \\
\text { malnutrition, the sensitivity was } 72.4 \% \text { for the APMT-DH (cu-toff } \\
\text { point }=13.4 \mathrm{~mm} \text { ) and } 77.3 \% \text { for the APMT-NDH (cu-toff point }=13 \text {, } \\
1 \mathrm{~mm} \text { ); the specificity was } 100 \% \text { for both. } \\
\text { *The APMT classification in both hands presented associations with } \\
\text { current weight, BMI, BC, TSF and BMC. }\end{array}$ \\
\hline $\begin{array}{l}\text { Lameu et al } \\
(2004)^{(5)}\end{array}$ & $\begin{array}{l}\text { APMT-DH = } \\
12.5 \pm 2.9 \\
\mathrm{~mm} .\end{array}$ & $\begin{array}{l}\text { APMT-DH } \mathrm{H}^{\mathrm{a}}= \\
10.5 \pm 2.3 \\
\mathrm{~mm} .\end{array}$ & $\begin{array}{l}\text { APMT-DH = } \\
11.5 \pm 2.8 \\
\mathrm{~mm}\end{array}$ & $\begin{array}{l}\text { * The APMT showed correlations with BMI }(r=0.40), \text { BMC }(r= \\
0.42) \text {, BMS }(r=0.40) \text {, and CC }(r=0.36) \text { but were not correlated with } \\
\text { fat, such as TSF and BFA } \\
\text { * APMT presented an association with age: APMT increased progres- } \\
\text { sively to } 46-65 \text { years, followed by a significant reduction over } 65 \\
\text { years.. }\end{array}$ \\
\hline
\end{tabular}

Notes: Brachial Fat Area - BFA; Brachial Muscle Area - BMA; Corrected Brachial Muscle Area - CBMA; Global Subjective Assessment - GSA; well nourished - GSA-a; moderately malnourished - GSA-B; severely malnourished - GSA-C; Brachial Circumference - BC; Waist Circumference - WC; Brachial Muscle Circumference - BMC; Calf Circumference - CC; X-Ray Dual-Emission Densitometry - DEXA; Adductor Pollicis Muscle Thickness - APMT; Adductor Pollicis Muscle Thickness of the Right Hand - APMT-RH; Adductor Pollicis Muscle Thickness of the Left Hand - APMT-LH; Adductor Pollicis Muscle Thickness of the Dominant Hand - APMT-DH; Adductor Pollicis Muscle Thickness of the non-dominant hand - APMT-NDH; Confidence Interval - Cl; Body Mass Index - BMI; Muscle Mass Index - MMI; Muscle Mass - MM; Not Reported - NR; Triceps Skin Fold - TSF; Receiver Operating Characteristic - ROC; Relative Risk - RR; + the APMT measurement was performed on the arm without vascular access; $\neq$ Variable described by median(interquartile range); ${ }^{2}$ Statistically significant difference between genders ( $\left.P<0.05\right) ; \quad b$ Statistically significant difference between the scoring sides of the APMT $(P<0.05)$.

\section{DISCUSSION}

In the present study, it was verified that APMT can be evaluated at different ages and clinical conditions, presenting higher values in younger, male and dominant individuals. The mean value varied widely, ranging from $7.3 \pm 2.7 \mathrm{~mm}$ to $16.2 \pm$ $4.3 \mathrm{~mm}$. In most studies, APMT was associated/correlated with nutritional status and/or muscle mass markers.

It is recognized that gender and age are determinants of muscle content, justifying the findings in common. The composition of skeletal muscle mass is influenced by testosterone levels, which is why men often have higher muscle density. However, the advancement of age reduces the amount of type 2 fibers due to the neurogenic changes that induce denervation, which, together with its lower mitochondrial adenosine triphosphate production, leads to a reduction in muscle mass ${ }^{(29)}$.

Another factor that seems to interfere in APMT is laterality, since the dominant hand presents values greater than the non-dominant one. Although there is no consensus on the side to be evaluated, most studies opted for the dominant hand, as did the pioneering work of Lameu et $\mathrm{a}^{(5)}$. A possible justification for this choice would be because this muscle is responsible for achieving the opposition of the thumb, a movement present in almost all routine activities, being mostly required in the dominant hand. Thus, there is a tendency to prefer the measurement of this hand, since the most exercised muscle tends to atrophy more rapidly in a situation of malnutrition ${ }^{(6)}$. 
It is suggested that APMT be influenced by other variables, such as the bone complexion ${ }^{(5)}$ - there being a progressive increase of the measure according to the body size - and the accomplishment of manual works ${ }^{(8)}$.

Race can also contribute to differences in values. Research has shown that blackand Hispanic people have higher bone mineral density and muscle mass than whites ${ }^{(30-31)}$. According to Ghorabi et $\mathrm{al}^{(24)}$, who evaluated Iranians, this may be a reason for the high APMT values found in their study. However, the results of Lameu et $\mathrm{al}^{(5)}$ did not present variations according to race. Except for the two studies mentioned above, the others did not consider the racial characteristics in the analyzes, which may represent a bias.

It is known that nutritional deficit, energy catabolism, diseases, physical inactivity and decrease of the work activity lead to the muscular depletion and, consequently, the reduction of $\mathrm{APMT}^{(5-7)}$. Thus, it is expected that patients who are ill and/or hospitalized will have lower values than the healthy population. In fact, it was found that the mean values found in the studies with healthy individuals ${ }^{(5,19,26)}$ were higher than those from studies with HIV-positive individuals ${ }^{(21)}$, ICU patients ${ }^{(24)}$, and on hemodialysis ${ }^{(27)}$. notwithstanding, other studies carried out with sick populations showed higher mean values than the healthy population, such as those performed with HIV-infected outpatients ${ }^{(20)}$, patients in the ICU ${ }^{(23)}$ and individuals who are candidates for large-scale surgery in the gastrointestinal tract $t^{(7)}$.

Regarding the different APMT values, some considerations should be reported. First, as mentioned previously, the characteristics of the sample (sex, age, race, body size, nutritional and health conditions) influence the results ${ }^{(5-7)}$. Another factor that may reflect differences are methodological inadequacies. According to Gonzalez et $\mathrm{al}^{(8)}$, research that identifies greatly discrepant values may be based on errors due to intra/inter-rater variability and incorrect anatomical point clamping; really low measures actually represent the thickness of the skinfold near the muscle, rather than the $\mathrm{APMT}^{(19)}$. The calibration and the type of instrument adopted for calibration also interfere. Cyrino et $\mathrm{al}^{(32)}$, when comparing the means of thickness of skinfolds using the Lange ${ }^{\circledast}$ and Cescorf ${ }^{\circledR}$ adipiometers, found differences between them, and Lange ${ }^{\circledR}$ presented superior measurements.

The studies showed APMT correlations with other nutritional status assessment methods, for example: weight, BMI, GSA, $B C, B M C, B M A, C B M A, C C, M M$ and $M M^{(5,7,18-26,28)}$. This suggests that the measure in question is indicative of nutritional status and muscle mass. It is emphasized that only the study by Bieleman et $\mathrm{al}^{(16)}$ associated the APMT with the muscular mass measured by an instrument considered gold standard - dual X-ray densitometry (DEXA) -, which accentuates a limitation of the other evidence.

The measurement was also correlated with creatinine and albumin, a fact that indicates the possibility of APMT to reflect the visceral protein content ${ }^{(18,27)}$. However, all these correlations were weak or moderate $(r<0.70)$ and therefore it is recommended that the interpretation of results be cautious. The demographic and clinical differences between populations surveyed, the size of samples and possible inaccuracies of anthropometric measurements are some justifications for slowing these correlations ${ }^{(32-33)}$.
In a recent systematic review, $\mathrm{Al}-\mathrm{Gindan}$ et $\mathrm{al}^{(34)}$ demonstrated that anthropometric measures overestimate muscle mass when compared to a reference standard. Nonetheless, the authors emphasized that there is insufficient evidence that locally assessed muscle mass - through circumferences and skinfold thicknesses - can be used to accurately estimate muscle mass throughout the body. However, these measures have several advantages, such as simplicity and ease of measurement, speed and low cost, besides being non-invasive and providing immediate results, characteristics that make them largely used in clinical practice ${ }^{(35)}$.

Some restrictions on the use of APMT should also be specified. There are no studies that have evaluated its intra/inter-rater reproducibility, which points to the relevance of professional training in obtaining this measure ${ }^{(27)}$. Factors such as the position of the individual during the measurement, the dominant hand and the instrument used may influence $\mathrm{it}^{(28)}$. In addition, if the adipometer is not applied at the correct anatomical point, the measurement will not correspond to the real APMT value ${ }^{(8)}$. Another limitation is the absence of specific reference standards for different life cycles and clinical conditions. It should be noted that this measure has not yet been evaluated in younger populations (children and adolescents).

Future studies should measure the reliability of APMT gauging intra/inter-evaluators, analyze the applicability of the measure in children and adolescents, as well as submit probabilistic samples of healthy and unhealthy individuals from different age groups to the analyzes in order to establish cutoff points, considering age, sex, race, hand dominance and clinical condition to detect the risk of malnutrition. Even more fundamental are studies comparing APMT with instruments considered gold standard in body composition assessment - hydrostatic weighing, plethysmography and DEXA, for example - to reinforce the use of this parameter. New longitudinal studies should be encouraged to clarify the causal inference and establish the usefulness of APMT to evaluate changes after nutritional interventions.

\section{Limitations of the study}

Among the limitations of the studies included in this review are: (a) the types of design (11 of the 13 articles were of cross-sectional design, which makes it difficult to interpret the mechanisms that influence APMT values and makes it impossible to determine causality); (b) the size of samples (in many, the sample calculations were not completely described, fact that limits the generalizations of the findings); and (c) the data analyzes (adjustments of possible confounding variables were not always performed).

Contributions to the areas of Nursing, Health or Public Policy Health services demand simple and low cost anthropometric indicators, with clinical relevance and pathophysiological coherence, destined to the complementary evaluation of nutritional status, such as APMT. In this context, the present review study stands out for relevance and contemporaneity. Through a systematic synthesis of the literature it was possible to verify that the APMT is a promising instrument for diagnosis/monitoring of adult and elderly individuals of both sexes in different clinical conditions, thus encouraging their use by health professionals, as well as further research to remedy remaining gaps. 


\section{CONCLUSION}

It is concluded that APMT evaluation can be used in different populations and is able to estimate nutritional status and muscle mass, since it was correlated, even weakly or moderately, with the respective anthropometric indicators: weight, BMI, GSA, $\mathrm{BC}, \mathrm{BMC}, \mathrm{BMA}, \mathrm{CBMA}, \mathrm{CC}, \mathrm{MM}$ and $\mathrm{MMI}$.

The use of this measure is relatively recent and, although the methodology for its evaluation is well defined, some questions lack clarification, for example: intra/interrater reliability, ideal laterality and calibration influences and type of adipometer used for gauging. In addition, it is necessary to identify cutoff points for the classification of nutritional status.

Due to the limitations, caution is recommended for its interpretation. In addition, it is suggested that it be used in a complementary way in the nutritional evaluation, not constituting a single diagnostic/monitoring parameter.

\section{REFERENCES}

1. Thibault R, Genton L, Pichard C. Body composition: why, when and for who? Clin Nutr[Internet]. 2012[cited 2017 Dec 12];31(4):43547. Available from: https://linkinghub.elsevier.com/retrieve/pii/S0261-5614(11)00243-3

2. Leal VO, Stockler-Pinto MB, Farage NE, Aranha LN, Fouque D, Anjos LA, et al. Handgrip strength and its dialysis determinants in hemodialysis patients. Nutrition[Internet]. 2011[cited 2017 Dec 12];27(11-12):1125-9. Available from: https://linkinghub.elsevier. com/retrieve/pii/S0899-9007(11)00010-4

3. Bourdel-Marchasson I, Joseph PA, Dehail P, Biran M, Fauz P, Rainfray M, et al. Functional and metabolic early changes in calf muscle occurring during nutritional repletion in malnourished elderly patients. Am J Clin Nutr[Internet]. 2001[cited 2017 Dec 12];73(4):832-8. Available from: https://academic.oup.com/ajcn/article-lookup/doi/10.1093/ajcn/73.4.832

4. Waitzberg DL, Terra RM. Função muscular e sua relação com nutrição e desnutrição. In: Waitzberg DL. Nutrição oral, enteral e parenteral na prática clínica. 3.ed. São Paulo: Atheneu; 2006. p. 321-5.

5. Lameu EB, Gerude MF, Campos AC, Luiz RR. The thickness of the adductor pollicis muscle reflects the muscle compartment and may be used as a new anthropometric parameter for nutritional assessment. Curr Opin Clin Nutr Metab Care[Internet]. 2004[cited 2017 Dec 12];7(3):293-301. Available from: https://www.ncbi.nlm.nih.gov/pubmed/15075921

6. Andrade PV, Lameu EB. Espessura do músculo adutor do polegar: um novo indicador prognóstico em pacientes clínicos. Rev Bras Nutr Clín. 2007;22(1):28-35.

7. Bragagnolo R, Caporossi FS, Dock-Nascimento DB, Aguilar-Nascimento JE. Espessura do músculo adutor do polegar: um método rápido e confiável na avaliação nutricional de pacientes cirúrgicos. Rev Col Bras Cir[Internet]. 2009[cited 2017 Dec 12];36(5):3716. Available from: http://www.scielo.br/pdf/rcbc/v36n5/03.pdf

8. Gonzalez MC, Duarte RR, Budziareck MB. Adductor pollicis muscle: reference values of its thickness in a healthy population. Clin Nutr[Internet]. 2010;29(2):268-71. Available from: https://linkinghub.elsevier.com/retrieve/pii/S0261-5614(09)00176-9

9. Pereira CA, Moreno JG, El Kik RM. Utilização da espessura do músculo adutor do polegar na avaliação nutricional. Rev Ciênc Saúde[Internet]. 2014[cited 2017 Dec 12];7(2):109-14. Available from: http://revistaseletronicas.pucrs.br/ojs/index.php/faenfi/ article/view/16626

10. Lew $\mathrm{CH}$, Ong F, Miller M. Validity of the adductor pollicis muscle as a component of nutritional screening in the hospital setting: a systematic review. Clin Nutr ESPEN[Internet]. 2016[cited 2017 Dec 12];16:1-7. Available from: https://linkinghub.elsevier.com/ retrieve/pii/S2405-4577(16)30264-9

11. Galvão TF, Pansani TS, Harrad D. Principais itens para relatar revisões sistemáticas e meta-análises: a recomendação PRISMA. Epidemiol Serv Saúde[Internet]. 2015[cited 2017 Dec 12];24(2):35-42. Available from: http://www.scielo.br/pdf/ress/v24n2/22379622-ress-24-02-00335.pdf

12. Edwards RH, Young A, Hosking GP. Human skeletal muscle function: description of tests and normal values. Clin Sci Mol Med[Internet]. 1977[cited 2017 Dec 12];52(3):283-90. Available from: https://www.ncbi.nlm.nih.gov/pubmed/844260

13. Eikermann $\mathrm{M}$, Groeben $\mathrm{H}$, Husing J, Peters J. Accelerometry of adductor pollicis muscle predicts recovery of respiratory function from neuromuscular blockade. Anesthesiol[Internet]. 2003[cited 2017 Dec 12];98(6):1333-7. Available from: http://anesthesiology. pubs.asahq.org/article.aspx? volume $=98 \&$ page $=1333$

14. Lameu E, Gerude MF. Músculo adutor do polegar. In: Lameu E, (Ed.). Clínica Nutricional. Rio de Janeiro, RJ: Editora Revinter. 2005: p. 189-96.

15. Armstrong R, Waters E, Jackson N, Oliver S, Popay J, Shepherd J, et al. Guidelines for systematic reviews of health promotion and public health interventions. Australia: Melbourne University; 2007.

16. Murad MH, Montori VM, Loannidis JPA, Jaeschke R, Devereaux PJ, Prasad K, et al. How to read a systematic review and meta-analysis and apply the results to patient care users guides to the medical literature. JAMA[Internet]. 2014[cited 2017 Dec 12];312(2):171-9. Available from: https://jamanetwork.com/journals/jama/fullarticle/10.1001/jama.2014.5559

17. Costa CAD, Tonial CT, Garcia PCR. Association between nutritional status and outcomes in critically-ill pediatric patients-a systematic 
review. J Pediatr[Internet]. 2016[cited 2017 Dec 12];92(3):223-9. Available from: http://dx.doi.org/10.1016/j.jped.2015.09.005

18. Oliveira CMC, Kubrusly M, Mota RS, Choukroun G, Brandão Neto J, Silva CAB. Adductor pollicis muscle thickness: a promising anthropometric parameter for patients with chronic renal failure. J Ren Nutr[Internet]. 2012[cited 2017 Dec 12];22(3):307-16. Available from: https://www.jrnjournal.org/article/S1051-2276(11)00149-X/fulltext

19. Bielemann RM, Horta BL, Orlandi SP, Barbosa-Silva TG, Gonzalez, MC, Assunção MC, et al. Is adductor pollicis muscle thickness a good predictor of lean mass in adults? Clin Nutr[Internet]. 2016[cited 2017 Dec 12];35(5):1073-7. Available from: https://linkinghub. elsevier.com/retrieve/pii/S0261-5614(15)00201-0

20. Cortez AF, Tolentino JC, Aguiar MRA, Elarrat RM, Passos RBF. Association between adductor pollicis muscle thickness, anthropometric and immunological parameters in HIV-positive patients. Clin Nutr ESPEN[Internet]. 2016[cited 2017 Dec 12];17:105-9. Available from: https://www.sciencedirect.com/science/article/pii/S2405457716302753

21. Neves AM, Führer CD, Almeida JCD, Hammes TO. Músculo adutor do polegar como ferramenta de avaliação nutricional em pacientes portadores do vírus da imunodeficiência humana. Clin Biomed Res[Internet]. 2016[cited 2017 Dec 12];36(4):214-21. Available from: http://seer.ufrgs.br/index.php/hcpa/article/view/66344

22. Valente KP, Silva NMF, Faioli AB, Barreto MA, Moraes RAG, Guandalini VR. Espessura do músculo adutor do polegar na avaliação nutricional de pacientes cirúrgicos. Einstein[Internet]. 2016[cited 2017 Dec 12];14(1):18-24. Available from: www.scielo.br/pdf/ eins/v14n1/pt_1679-4508-eins-14-1-0018.pdf

23. Ghorabi S, Ardehali H, Amiri Z, Shariatpanahi ZV. Association of the adductor pollicis muscle thickness with clinical outcomes in intensive care unit patients. Nutr Clin Pract[Internet]. 2016[cited 2017 Dec 12];31(4):523-6. Available from: https://doi. org/10.1177/0884533615621547

24. Karst FP, Monteiro R, Vieira SB. Relationship between adductor pollicis muscle thickness and subjective global assessment in a cardiac intensive care unit. Rev Bras Ter Intensiva[Internet]. 2015[cited 2017 Dec 12];27(4):369-75. Available from: http://www. scielo.br/pdf/rbti/v27n4/en_0103-507X-rbti-27-04-0369.pdf

25. Gonzalez MC, Duarte RRP, Orlandi SP, Bielemann RM, Barbosa-Silva TG. Adductor pollicis muscle: a study about its use as a nutritional parameter in surgical patients. Clin Nutr[Internet]. 2015[cited 2017 Dec 12];34(5):1025-9. Available from: https:// linkinghub.elsevier.com/retrieve/pii/S0261-5614(14)00270-2

26. Ghorabi S, Vahdat Shariatpanahi Z, Amiri Z. Measurement of adductor pollicis muscle thickness in a healthy population in Iran and its correlation with other anthropometric parameters. Mal J Nutr[Internet]. 2014[cited 2017 Dec 12];20(2):237-43. Available from: https://www.researchgate.net/publication/270566213_Measurement_of_Adductor_Pollicis_Muscle_Thickness_in_a_Healthy_ Population_in_Iran_and_Its_Correlation_with_other_Anthropometric_Parameters

27. Pereira RA, Caetano AL, Cuppari L, Kamimura MA. Adductor pollicis muscle thickness as a predictor of handgrip strength in hemodialysis patients. J Bras Nefrol[Internet]. 2013[cited 2017 Dec 12];35(3):177-84. Available from: http://www.scielo.br/pdf/ jbn/v35n3/en_v35n3a03.pdf

28. Cobero FE, Gomes MCB, Silva AP, Bernardi JLD, McLellan KCP. Adductor pollicis muscle measurement is associated with anthropometric indicator of muscle mass and fat mass of hospitalized patients. J Brazilian Soc Food Nutr[Internet]. 2012[cited 2017 Dec 12];37(2):174-82. Available from: http://fi-admin.bvsalud.org/document/view/mrzgj

29. Schiaffino S, Reggiani C. Fiber types in mammalian skeletal muscles. Physiol Rev[Internet]. 2011[cited 2017 Dec 12];91(4):1447531. Available from: https://www.ncbi.nlm.nih.gov/pubmed/22013216

30. Wagner DR, Heyward VH. Measures of body composition in blacks and whites: a comparative review. Am J Clin Nutr[Internet]. 2000[cited 2017 Dec 12];71(6):1392-402. Available from: https://academic.oup.com/ajcn/article-lookup/doi/10.1093/ajcn/71.6.1392

31. Araujo AB, Chiu GR, Kupelian V, Hall SA, Williams RE, Clark RV, et al. Lean mass, muscle strength, and physical function in a diverse population of men: a population-based cross-sectional study. BMC Public Health[Internet]. 2010[cited 2017 Dec 12];10:508. Available from: https://www.ncbi.nlm.nih.gov/pmc/articles/PMC2933725/

32. Cyrino ES, Okano AH, Glaner MF, Romanzini M, Gobbo LA, Makoski A, et al. Impacto da utilização de diferentes compassos de dobras cutâneas para a análise da composição corporal. Rev Bras Med Esp[Internet]. 2003[cited 2017 Dec 12];9(3):145-9. Available from: www.scielo.br/pdf/rbme/v9n3/17264.pdf

33. Guo SS, Siervogel RM, Chumlea C. Epidemiological applications of body composition: the effects and adjustment of measurement errors. Ann N Y Acad Sci[Internet]. 2000[cited 2017 Dec 12];904(1):312-6. Available from: https://nyaspubs.onlinelibrary.wiley. com/doi/pdf/10.1111/j.1749-6632.2000.tb06473.x

34. Al-Gindan YY, Hankey CR, Leslie W, Govan L, Lean ME. Predicting muscle mass from anthropometry using magnetic resonance imaging as reference: a systematic review. Nutr Rev[Internet]. 2014[cited 2017 Dec 12];72(2):113-26. Available from: https:// academic.oup.com/nutritionreviews/article-lookup/doi/10.1111/nure.12096

35. Lee RC, Wang ZM, Heymsfield SB. Skeletal muscle mass and aging: regional and whole-body measurement methods. Can J Appl Physiol[Internet]. 2001[cited 2017 Dec 12];26(1):102-22. Available from: https://www.ncbi.nlm.nih.gov/pubmed/11173672 